\title{
ON SOME QUESTIONS OF ROMAN PUBLIC LAW.
}

By Professor J. S. REID, M.A. Litt.D. LL.D.

The proposals which were made at Rome from time to time to grant to "Latini" the privileges of the provocatio, wholly or in part, raise questions which touch closely the history of the evolution of constitutional and criminal law at Rome during the republican age. So far as is known, the first attempt to sever the provocatio from the general rights of the Roman franchise, and to bestow it on Italian allies, was made by M. Fulvius Flaccus, consul in 125 B.c. the associate of C. Gracchus, who perished with him. According to Valerius Maximus, ix, 5, I, he introduced "perniciosissimas rei publicae leges (rhetorical plural) de civitate Italiae danda et de provocatione ad populum eorum qui civitatem mutare noluissent." The word Italiae is not in the manuscripts, but that this word rather than Latinis should be inserted, is made highly probable by passages in Appian, B.C. i, 34, and Plutarch, C. Gracchus,

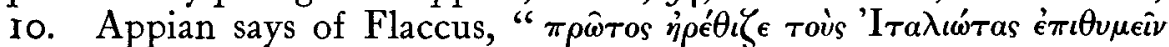

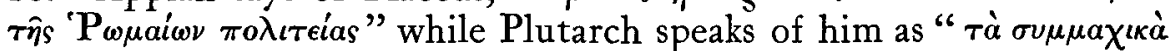

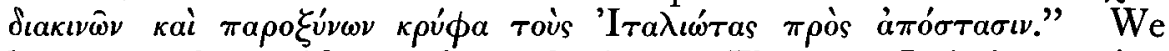
have no other evidence about the law of Flaccus. It is interesting to note the assumption that some of the allies would not be ready to accept the Roman citizenship. It was not to be forced on individuals, and we must believe that all enfranchising proposals left the municipalities free to accept or reject the gift. This was certainly the case with the lex Iulia of 90 B.c. No doubt Flaccus contemplated giving the provocatio both to individuals whose townships might reject the offer of the franchise and to individuals who might disagree with the majority of their fellow-townsmen if the vote went in favour of acceptance. It is clear that, so far as the civitas goes, the democrats never separated the fortunes of the Latins from those of the other allies. Some utterances of Plutarch and Appian have led to a different opinion with regard to the enfranchising bill of C. Gracchus, but they are thoroughly confused. In B.C. i, 23 Appian implies a difference between Latins and Italians, but does not state it intelligibly, while in i, 34 he speaks of the measure of Gracchus as a counterpart of that of Flaccus (

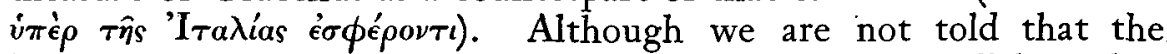
bill of Gracchus contained a clause about provocatio parallel to that in the bill of Flaccus, it can hardly have been otherwise. The clause to some extent resembles the provisions of the lex Plautia Papiria of 89 в.c. which enabled individuals, as individuals, in some cases, to claim the civitas. 
Both Gracchus and Flaccus, therefore, were prepared to extend the provocatio to any members of allied communities who did not desire to exchange completely their municipal citizenship for the Roman burgess rights. It is therefore strange that, so far as the extant fragments show, the lex Acilia repetundarum, of which Gracchus was the inspirer, gives to any non-Roman who successfully prosecutes, whatever his origin, the right to the full franchise, but grants to the Latin alone the privilege of choosing between the civitas and the provocatio. That Gracchus in his speeches bewailed the mistreatment of other Italian allies than the Latins is known (Gell. x, 3), and probably in some portion of the lex Acilia which has not come down to us the two classes of socii were placed on an equal footing. It has been generally assumed from a passage in Cicero's Pro Balbo, $\$ \S 54,55$, that the lex Servilia repetundarum of II I B.c. restricted to the Latins the reward of the civitas for a successful prosecution under the law. The restriction is improbable in itself, since the statute was carried by a thoroughpaced democrat, at a moment when his party was in the ascendant. If Cicero's words are carefully examined, the inference that has been drawn from them will be seen to be unjustified. The opponents of Balbus had argued, on highly technical grounds, that to make a member of a civitas foederata a Roman citizen was illegal. Cicero counters this by reference to the Latins, who were undoubtedly foederati, and quotes examples of Latins who, by securing a conviction on a charge of repetundae, had become Romans, under the provisions of the lex Servilia; but he neither asserts nor implies that it was impossible for others than Latins to secure the same reward. $\mathrm{He}$ merely says that the Latins, who are selected by him as examples of foederati, were not deprived of the privilege by the lex Servilia, and that law is mentioned because it was the last of the statutes enacted concerning repetundae before the whole body of Latins obtained the Roman franchise. The epithet acerbissima applied to the law merely indicates Cicero's opinion, given also elsewhere, that it was vindictive against the nobles who were tried under it. The gift of the civitas remained under some of the criminal statutes which followed, but after the Social War there was no reason for the choice between it and the provocatio. Every one would choose the civitas.

Next comes a narrower question, about which opinions have been sharply divergent: was that part of the provocatio enjoyed by Romans, which guaranteed them against scourging, ever accorded to the Latins? We encounter this question at three points of republican history, in connexion with (a) the legislative proposals of the elder M. Livius Drusus, the opponent of the younger Gracchus; (b) an incident of the Jugurthine war, recorded by Sallust; (c) Caesar's colony of Novum Comum, which he founded in pursuance of a lex 
Vatinia, passed in 59 в.с. by Vatinius, at that time his political man-of-all-work. The passages in the ancient authorities bearing upon these events present difficulties, which I propose to examine, taking the occurrences in the inverse order of their dates.

Scholars have divided on the issue whether Novum Comum was a colony with Latin rights or with burgess privileges. Let us see what inferences can fairly be drawn from the words of ancient writers who make mention of its establishment.

Strabo, p. 213. Having stated that Mediolanum and Verona were great cities, while Brixia, Mantua, Regium (Lepidum) and Comum were of less importance, Strabo gives the history of Comum :

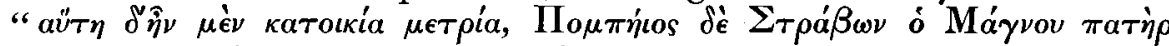

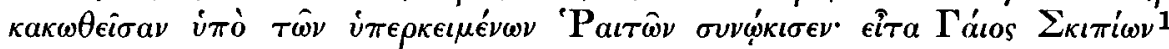

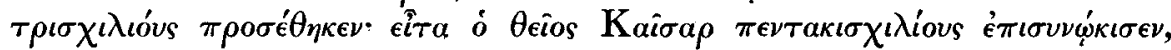

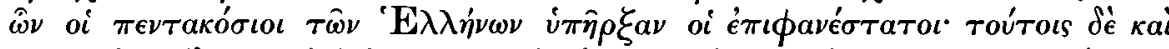

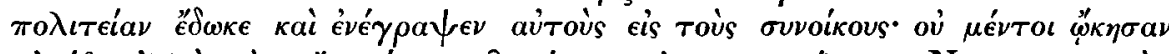

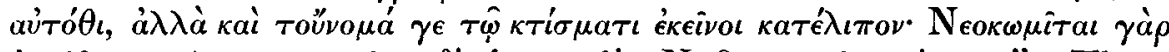

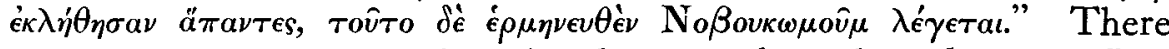
are one or two corruptions in the text, but they do not affect our subject. The information which Strabo gives of the Italian cities in general is very scanty. At the outset of his account of the towns in the north of the peninsula he only distinguishes broadly between towns which existed before the Roman conquest and towns founded later, and the whole of the later are called ' $\mathbf{P} \omega \mu$ ai $^{\prime} \omega$ àmoikia (p. 216). When he goes beyond this, his statements are loose.

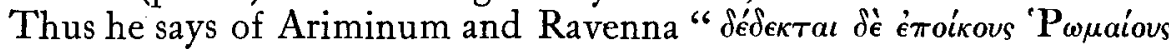

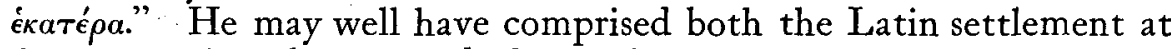
Ariminum in 268 B.c. and the settlement of veterans there in the time of the Triumvirate, under the heading "P iii, 66, 69, similarly describes Placentia as "P none but Latins had been settled there. As concerns Ravenna, nothing is known of either Latins or Romans having been sent there as colonists. It is clear that if Strabo had called Novum Comum a Roman colony, it might still have been a Latin colony in the technical sense. The distinction between the two old series of colonies in the peninsula had vanished long before he wrote, and did not interest him. But if his language be scanned with care, it will be seen that he does draw a distinction between the 500 distinguished Greeks who were associated with the new foundation, and the remainder of the colonists. It is only in reference to these nominal colonists that Strabo mentions the bestowal of the $\pi$ oגıteía. And a passage in Cicero, Ad Fam. xiii, 35 ,

1 This Gaius Scipio cannot be identified. The only Scipio who is likely to have been concerned between 89 and 59 in strengthening Comum is L. Scipio Asiagenus, consul in 8. The Greek writers, especially Appian, often give wrong praenomina. Thus $Q$. Caecilius Metellus Pius Scipio is repeatedly called Lucius by Appian. 
enables us to say definitely that this was the Roman citizenship: "C. Avianius Philoxenus antiquus est hospes meus et praeter hospitium valde etiam familiaris; quem Cacsar meo beneficio in Novocomensis rettulit." The numerous analogies in the names of enfranchised Greeks compel us to believe that Philoxenus became a Roman not a Latin citizen. The coincidence between Strabo's

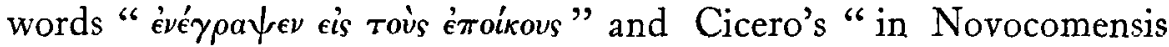
rettulit" will be observed. The only connexion which these Greeks had with the place consisted in the entry of their names on the town register. With Cicero's expression meo beneficio we may compare In Verrem, ii, 4, 37: "Q. Lutatius Diodorus, qui Catuli beneficio ab L. Sulla civis Romanus factus est."

Are we obliged to believe that the other 4,500 settlers were or became Roman citizens? I shall show cause presently for thinking that this was not the case. Why then were these Greeks enrolled on the register? Caesar had been empowered by the lex Vatinia to bestow the citizenship on a certain number of aliens, not in general terms, but specially in connexion with the new settlement. This was a regular practice when the older burgess colonies were created, but we do not hear of the boon being bestowed on so large a number of recipients at once. The colonial law of Saturninus named Marius as founder of the new communities authorised by it, and allowed him to create three new Roman citizens for each place (" in singulas colonias ternos civis Romanos," Cicero says in Pro Balbo $\$ 49$ ). Ihne in his History (v, 153, English edition) has a long note in which he attempts to prove that for ternos in this passage we should read trecenos. It is indeed rather strange that Saturninus, who wished to enfranchise all Italy at a blow, should have fixed this low figure, and that Marius, who on a celebrated occasion during his campaigns against the northern barbarians, turned into Romans in the twinkling of an eye two whole cohorts of men from Camerinum, should have accepted the number. But the megalomania which affected leaders during the dying days of the republic. would naturally induce Caesar to go a long way beyond his predecessors in this detail of colonial foundation, just as it led him to accept a supplicatio for victory, lasting through fifty days, in place of the one day with which the men of old were content. The power of enfranchising men in the course of a campaign as a reward for service rested on the possession of the full imperium, but apparently did not usually depend, as did the similar power exercised on the foundation of a colony, on any special enactment. So far as is known, the extraordinary action of Marius in conferring the boon upon two cohorts at once was never arraigned as illegal. In view of this fact, no stress can be laid on those versions of the anecdote which state that Marius, when criticised, answered that he could not hear the voice of "the statutes" or "the civil 
law" amid the din of arms. Custom, not law, seems to have regulated the general's prerogative. Three statutes might perhaps be quoted to prove the contrary. A lex Gellia Cornelia, passed in 72 B.c. is mentioned by Cicero in his speech for Balbus ( $\$$ I9) as having validated gifts of the citizenship made by Pompey "de consili sententia." But the peculiar position of Pompey at the time may have made this measure advisable rather than necessary. He held the imperium, but had acquired it in an irregular manner, and it may on that ground have been urged that he had acted ultra vires. Elsewhere in the same speech, Cicero quotes five commanders who had in like manner enfranchised aliens, but in their case he makes no reference to special legislation. The association of the consilium with the general seems to indicate that the proceeding was customary and recognised. Again a record discovered recently shows that the lex Iulia of 90 B.c. contained provisions which authorised generals in the field to confer the status of Roman burgess on soldiers who had done good service. A whole turma of Spanish cavalry was thus rewarded, and the consilium sat with the general when the decision was taken. For this statutory authorisation there may have been special reasons, as for instance that enfranchisement was contemplated on a scale that went far beyond custom, particularly as it affected non-Italians. So with the lex Calpurnia of 89 B.c.

Apparently it was necessary, when the founder of a colony exercised his power of enfranchisement, that the names of the enfranchised should be enrolled on the local register. It seems to have been a somewhat inconvenient practice for men who, like these Greeks, had no intention of residing in the new town. It would to all appearance have been more suitable that they should have been attached to one of the urban tribes in Rome. But in the case of all exceptional enfranchisements, the assignment of a tribe was a purely personal matter, and as the old regulations for the census were in a state of decadence, any nominal connexion with Italy would be sufficient. If the familiar line of Ennius, "nos sumu' Romani qui fuimus ante Rudini," could be taken literally, it would mean that when the poet was made a citizen his name was entered on the lists only at Rome, not at Potentia or Pisaurum, the colonies which his patron Fulvius founded; but the line cannot be pressed so far.

It may be asked, Was it possible to create a new colony in which the colonists had not all the same legal status? Probably in quite early days it would not have been a possibility. There is good evidence that Romans who joined Latin colonies became ipso facto Latins. It appears, however, from a case reported by Livy, xxxiv, 42, that at least after 193 B.c. Latins could not acquire the Roman citizenship merely by joining a burgess colony. From the manner 
in which Livy tells the story, it is likely that this was a new restriction, and it does not appear that the Latins whom the decision affected were prevented from associating themselves with the Romans in the burgess colonies which were founded at the time. If so, these communities were composite. There is considerable probability that C. Gracchus, when he admitted allies to his burgess colonies, gave them full citizen rights; but this would be done by legislation. No precedents, however, would matter much to Caesar. Indeed, he seems to have founded Comum without a colleague, and thereby broke long established practice and anticipated the usage of the empire. There is no certain earlier example of a colony having been actually founded by a single commissioner. Caesar's newly created Romans did not become residents at Comum and therefore they caused no confusion in the administration of the town; but if they had been domiciled there, they would only have been in the same position as the men in the Latin municipalities who had acquired the Roman citizenship by holding a local magistracy. In the municipal law of Malaca, a Latin township, there is a provision whereby incolae, whether Romans or Latins, may vote at elections. There seems, therefore, to be no difficulty in the supposition that Caesar created a mixed community at Novum Comum. In this connexion an inscription found at Aosta a few years ago has some interest. It is dated 22 or 23 B.c. that is to say, only two or three years after Augustus founded the colony of Augusta Praetoria. It mentions "Salassi, qui se initio in coloniam contulerunt." Considering the severity with which Salassi had just been treated, it would be strange if even some among them who had done Rome service were permitted to acquire the full citizenship in a colony consisting mainly of veteran Praetorians, men whose Italian origin would be a matter to them of special pride, in view of the rules of enlistment in their corps. At the utmost these men, contrary to the view commonly accepted, must have received the Latinitas.

The impression that Caesar's settlers at Novum Comum had not all the same legal status is confirmed by the words of Suetonius, in his life of Iulius, c. 28: "nec contentus Marcellus provincias Caesari et privilegium eripere, rettulit etiam ut colonis quos rogatione Vatinia Novum Comum deduxisset, civitas adimeretur, quod per ambitionem et ultra praescriptum data esset." It is here distinctly implied that Caesar had been commissioned to create so many citizens and no more, and that he had exceeded the fixed number. It would be quite unnatural to interpret Suetonius as meaning that Caesar had added to the number of colonists, all Roman, whom he had been enjoined by the law to place at Novum Comum; or that all these colonists were to lose their Roman franchise because Caesar had exceeded his rights in creating Roman burgesses. 
The statement of Appian, B.C. ii, 26, is confused at some points,

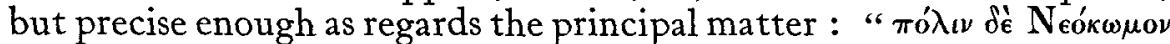

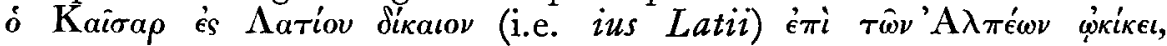

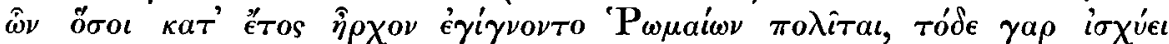

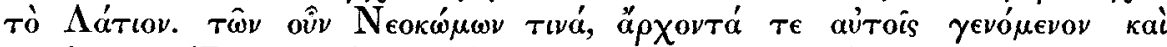

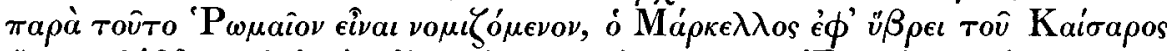

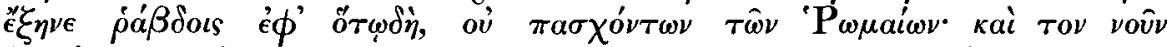

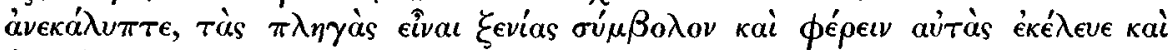

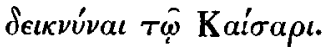

Clearly Appian regarded Novum Comum as a Latin colony. But to suppose that a man who had acquired the Roman franchise by the operation of the rule which gave it to men who had passed the magistracy, a rule which was general and had nothing to do with Caesar, could have been handled by Marcellus as other Romans were not handled (ov $\pi \alpha \chi^{\prime} \nu \tau \omega \nu \tau \hat{\omega} \nu$ 'P $\mathrm{P} \omega \mu \alpha{ }^{\prime} \omega \nu{ }^{1}$ ) is absurd. Marcellus is known as by no means a violent man. Cicero calls him "tardus et parum efficax." It is most unlikely that he would have committed

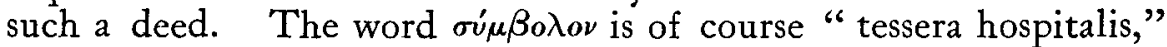
which, as Appian supposes, could only be given to a non-Roman.

Plutarch (Caesar, 29) has a somewhat different version of the

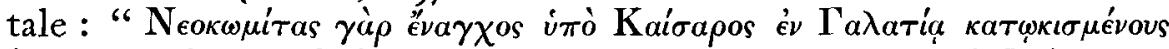

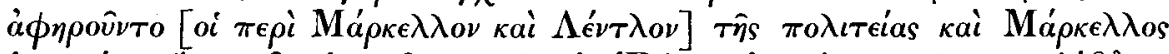

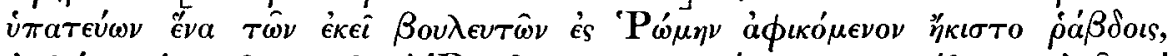

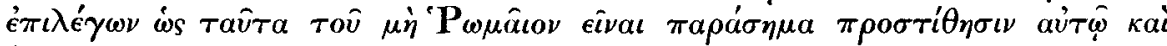

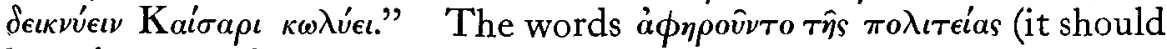
be $\tau \dot{\eta} \nu \pi \lambda_{\imath \tau \epsilon i a \nu}$ resemble "ut civitas adimeretur" in the passage

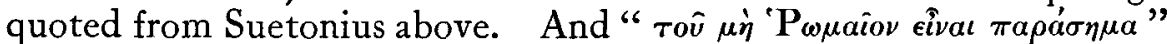
corresponds with " $\xi \in v^{\prime} a s \quad \sigma \nu \mu \beta o \lambda o v "$ in Appian, who also has

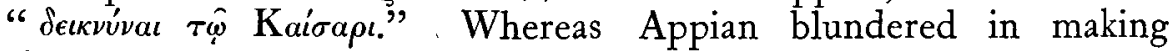
the man a past magistrate and therefore a Roman, Plutarch presents him as only a member of the local senate, and no Roman. Therefore, in Plutarch's view, Novum Comum does not possess citizen rights. But the words á Plutarch did not altogether understand the circumstances.

That Plutarch is wrong in speaking of Marcellus and Lentulus, consuls of 49 B.c. in relation to this occurrence, is made certain by a sentence in Cic. Ad Att. v, I I, 3. It was written from Athens early in June, 5I, when Marcellus, the cousin of the consul of 49, was in office with S. Sulpicius Rufus, the famous lawyer. It runs: "Marcellus foede in Comensi ; etsi enim magistratum non gesserat, erat tamen Transpadanus." This passage is unintelligible unless Novum Comum was a Latin colony. The reference to the magistracy would be meaningless; also the words erat tamen Transpadanus; for the Transpadani in general were notoriously Latins. Cicero

1 The word roviro has fallen out before $\tau \hat{\omega} \nu$. 
implies (a) that a consul ought to treat all Transpadani on the same principles; $(b)$ that Caesar's connexion with Novum Comum should have made no difference; (c) that Marcellus would not have acted as he did if his victim had not belonged to Caesar's colony. The words erat tamen Transpadanus do not appear to be exactly what Cicero wrote. After the very strong expression foede we might expect not merely a statement that the man was Transpadanus, but an indication that he was distinguished in his class. The extract from Plutarch suggests that decurio may have fallen out after enim; or perhaps erat has displaced senator, which occurs frequently to denote a local councillor, though not so commonly as decurio. The preceding words stand in a corrupt form in the Medicean MS. which gives sedendi comes for foede in Comensi. The $s$ of comes may represent the lost $s$ of senator; the rest of the corruption would be easy.

Two small points may be noticed in Cicero's language. In the first place he writes Comensi, though he has Novocomensis in Ad Fam. xiii, 35. This might indicate that after Caesar's new foundation there was a double community at Comum, as there was in a number of Italian towns after the establishment of the later military colonies. Sometimes the old inhabitants and the new had quite distinct municipal institutions; sometimes the two sets seem to have constituted a sort of federal municipality. But the supposition of two Latin communities side by side is improbable. Catullus used the name Novum Comum, but the shorter title ultimately prevailed. The word magistratum is correctly used, for all magistracies in a Latin town gave the right to the Roman citizenship. The number of the magistracies was not always the same. In some towns a large proportion of the local councillors must have been in possession of the franchise; in others the number would be smaller. It was perhaps to level inequalities of the kind that the maius Latium was invented, which gave every decurio the privilege. Till recently the maius Latium was known from a passage of Gaius only; but a few years ago an inscription was discovered on the site of Gigthis in northern Africa, which mentions it. The privilege, like the full citizenship and the ius Italicum, was then of course bestowed by the emperor only.

In his early days Caesar had taken a special interest in the Transpadani, who were anxious to exchange the Latinitas bestowed on them by the lex Pompeia, for the full civitas. Suetonius (Iul. c. 8) has a story to the effect that when he was returning from his quaestorship in Spain in the year 67, Caesar approached the "Latin colonies" there on the question, and would have roused them to some deed of daring (ad audendum aliquid) had not the consuls retained in Italy for a time legions destined for service in Cilicia. The tale is certainly, at least in part, apocryphal. When Suetonius 
speaks of "the Latin colonies" he means the whole of the Transpadani, whose rights were the same as those of the last series of older Latin colonies, the twelve which begin with Ariminum and end with Aquileia. In 65 the censors, Crassus and Catulus, quarrelled about the Transpadanes. Crassus wanted to admit them to the citizenship and Catulus blocked the proposal (Dio. xxxvii, 9). This may have had something to do with the passing of the fourth and last of the republican alien acts, in the same year, the lex Papia. In 63 C. Calpurnius Piso, consul of 67 , and afterwards governor for two years of Gallia Narbonensis, was prosecuted on a charge of repetundae, and Caesar lent his weight to the prosecution because Piso (who was defended by Cicero) had inflicted iniustum supplicium on a Transpadane (Sallust, Cat. c. 49). If he executed the man in the Transpadane region, which was not part of his province, his action was peculiarly irregular. Cicero, writing from his Pompeian villa to Atticus in April, 5I, mentions a rumour about the Transpadani, " eos iussos quattuorviros creare." Looking to all the information derivable from municipal inscriptions, we should not be justified in supposing that the change indicated of necessity an alteration in status. But Cicero took the rumour to mean that Caesar had presumed to bestow burgess rights on the whole of the Transpadani, making apparently an extreme and unprecedented use of the privilege of granting the citizenship which, being inherent in the imperium, later on made the emperor the source of the civitas even before the comitia ceased to exist. But Caelius, in a letter addressed to Cicero, then abroad, in May, of the same year, writes of the rumours and says that on his way to Rome from the south they were hot ("caluerunt") as far as Cumae, yet at Rome he found not a whisper of them, while Marcellus had suspended his action against Caesar. This gossip then about northern Italy had its birth in the south. Some writers have assumed the truth of the tale and have supposed that the outrage suffered by the senator of Novum Comum was an act of retaliation. The evidence does not bear out the conclusion, but obviously conservative feeling in Italy was nervous concerning Caesar and the Transpadanes. The continuous interest which he took in the question of their enfranchisement prompts the query why it was that he was unable to enfranchise them in 59, or even to plant a Roman colony among them, or even to select the 500 new citizens from among the Transpadanes, rather than the Greeks. The answer is not difficult. It would hardly have been possible to establish a new burgess town in the Transpadane region without giving all the inhabitants burgess rights, and in that case the provincial organisation of Gallia Cisalpina would not have been easy to maintain. The position of the Cispadane region was already sufficiently anomalous, as also was that of the two or three towns to the north of the river, which 
benefited by the lex Iulia, and which are ignored in the ordinary use of the term Transpadani. A selection of a few hundred of men for enfranchisement would only have aggravated discontent. For the entire incorporation of the province with Italy, the permanent conquest of Gaul was a necessity. The complete enfranchisement of the 500 Greeks enabled Caesar to gratify many Romans of importance. The enfranchised were probably all men of cultivation, on terms of intimacy with noble Roman families.

When Marcellus flogged the senator of Novum Comum, Cicero thought him seriously in error. But did he suppose him to have erred against law, policy, or custom only? The position of the Latins with regard to the punishment of scourging has been greatly discussed in connexion with a passage in Sallust, Iug. cc. 66, 67, 69. It is there stated that T. Turpilius Silanus, who was praefectus over the town of Vaga, was the only one of the Italici there who escaped with his life when the inhabitants conspired to place the town in Jugurtha's hands. The officers of the garrison were invited to banquets in different houses and by a concerted plot were massacred with this one exception. Then the common soldiers were cut down in the streets. The mention of Italici shows that all residents of Italian birth had been enrolled for the defence, as at Cirta during the same war. Similarly Caesar organised the conventus civium Romanorum at Lissus during his campaign against Pompey. Sallust did not know how Turpilius saved his life. When Metellus captured the town once more, he placed Turpilius on his trial, then "postquam sese parum expurgat, condemnatus verberatusque capite poenas solvit : nam is civis ex Latio erat." Was Turpilius a Roman or a Latin? Both views have had many supporters. The answer to this question depends in part on the answer to another: were Romans on service themselves at this time protected by law against scourging ? If they were not exempt (and a number of scholars have held this view) and Turpilius was a Roman, how is the addition of the words nam is civis ex Latio erat to be explained ? How did any connexion with Latium matter if he, being a Roman, was suffering a punishment to which all Romans were subject? If ex Latio means that he had once only possessed the ius Latii, why should Sallust drag in the fact? Did he think that some of his readers would know that the man had been a Latin, but would not know that he had ceased so to be ? The supposition has only to be stated to be rejected.

One thing is admittedly made certain by the passage: that the rights of Latins and Romans when on military service as regards discipline were different at the time. The natural, almost inevitable conclusion is that the Romans were in the superior position. It would need evidence of great strength to prove the contrary, and I shall show that such evidence does not exist. But before advancing 
to this, I will say something of the Latinity of the words is civis ex Latio erat. It has often been contended that civis in this connexion must mean "Roman citizen." It is of course true that when civis stands alone, unmodified by the context, that must be the sense. But the inhabitants of all municipalities, whether Roman, Latin or peregrin, freely called themselves cives or modita. The expression Latinus civis actually occurs in the lex Malacitana, and was doubtless common enough. In the leges we find civis prefixed to Romanus Latinus peregrinus, and applying to all three. The question then is whether the words ex Latio can so modify the meaning of civis as to indicate a member of a Latin community. The word Latium has three significations : (a) the region of Latium; $(b)$ the sum total of Latin municipia; $(c)$ the personal rights which are often denoted by Latinitas. Why should not $e x$ indicate origin from Latium in the second sense? After the material for this paper had been put together, an article by Mr. Caspari, in the Classical Quarterly for April, I9r I, treating of this matter, came into my hands. He supposes that civis ex Latio means "a Roman citizen after having been a Latin." I have already shown a substantial difficulty in the way of this interpretation; but the form of expression is also against it. So far as the use of the preposition goes, no objection can be made, as parallels are to be found in a number of writers. But " a citizen out of Latium" or " after Latium," where Latium signifies " Latin rights," strikes me as an impossible manner of speaking. To express this, Sallust must have written ex Latino or rather civis Romanus ex Latino. The reasonable deduction from Sallust's language is that Turpilius was a Latin and liable to verbera or to execution after flogging, while the Romans who served him were not so liable. I put aside for the moment an idea, to which I will return later, that at the time in question the leges Porciae had forbidden the execution of a Roman soldier on service without appeal (provocatio), and that it is the execution of Turpilius, not the flogging, for which Sallust is giving a reason.

Plutarch, Mar. c. 8, tells the tale somewhat differently.

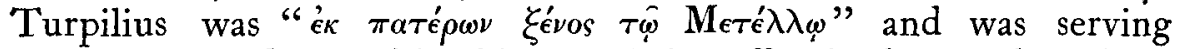
as praefectus fabrum. The history of this office is obscure, but there is nothing which shows that at this time it could only be given to a Roman citizen. Such indications as there are point the other way. The office, as is well known, placed its occupant in very close personal relation with the commander. It was in his gift, and would enable him to employ on his staff, and to give a title of ancient dignity to a capable officer who, not being a Roman senator, could not be a legatus, or not being a Roman, could not be a tribunus militum. The whole later history of the office connects it closely with municipalities outside Rome, in the provinces as well as in 
Italy; and this connexion is best explained by supposing that at an earlier time the commander's choice was unrestricted. 'The office was purely a staff, not a legionary one. Turpilius had centurions and military tribunes under his command in Vaga (Sall. c. 66), but this must often have happened with non-Romans attached to the cobors praetoria, especially at a time when each of the contingents sent from non-Roman towns was separately officered by townsmen. Sallust calls Turpilius praefectus oppidi, not a regular military title, but modelled on praefectus urbi; in both cases praefectus indicates a personal deputy or nominee. Plutarch goes on to tell how Turpilius had dealt justly and gently with the inhabitants of Vaga, who in gratitude took measures to secure his safety when they opened the gates to Jugurtha. Then Turpilius is charged with treacherously conniving at the surrender of the place. Marius is a member of the consilium and presses on the accused so savagely that Metellus is forced against his will to agree to the death penalty. The general tradition of the Jugurthine war makes it hard to understand why Metellus should have allowed himself to be terrorised by Marius. Probably it would not have happened had Turpilius been a Roman citizen. Plutarch's story goes on to say that after the execution the charge of treachery was absolutely disproved; but that Marius was delighted, because he could now throw on Metellus the blame for an unjust sentence. Hence the open quarrel between the two.

Another variant is given by Appian, Num. c. 2. Metellus destroyed the whole $\beta$ ov $\lambda \dot{\eta}$ of Vaga because they had betrayed the town to Jugurtha, and he put to death Turpilius ( ${ }^{\prime} \nu \delta \rho \alpha$ 'P $\left.\mathbf{P} \omega \mu \alpha \hat{i} o v\right)$

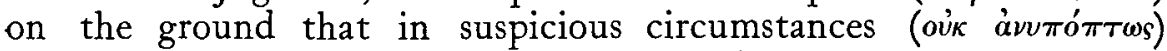
he had placed himself in the enemy's hands. From what has been said above, it will be seen that no safe conclusion could have been drawn from the description ${ }^{\prime \prime} \nu \delta \rho \alpha$ 'P $\boldsymbol{\omega} \mu \alpha \hat{i} \nu$ even if Polybius or Strabo had been the writer. Much less can the authority of Appian weigh in such a matter. For example, in his account of the Gracchan revolution he speaks of the Roman colonies in Italy without distinguishing between Latin and Roman, and sometimes uses the phrase 'I $\tau_{\alpha \lambda} \lambda_{\iota} \boldsymbol{\omega} \tau \alpha$ to denote all the Italian allies, while sometimes he applies it to the Roman citizens who lived in the country, as opposed to those domiciled in Rome, and again makes it so vague that his meaning cannot be exactly discerned. The fact that there was a guest-friendship between the family of Metellus and that of Turpilius raises a rather strong presumption (considering the date) that Turpilius was not a Roman, and proves at any rate that he had not a domicile in Rome. Gruter suggested that he belonged to the Latin town of Sora, where there were families of the name, which is rare in inscriptions.

We come now to the measure which the elder M. Livius Drusus, 
the rival of C. Gracchus, proposed, to relieve the Latins from the risk of being scourged. Our only authority is Plutarch, C. Gracchus,

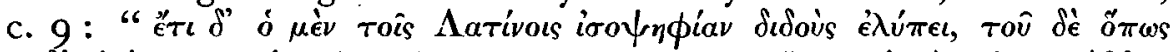

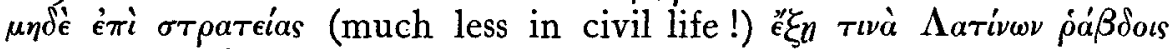

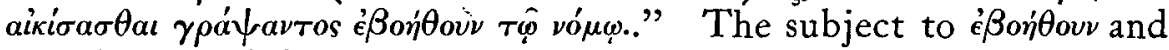
the object to é $\lambda \dot{u}^{\pi} \epsilon \epsilon$ is the senate. The passage is part of a rhetorical exposition of the action of the Drusus and the senate. His whole

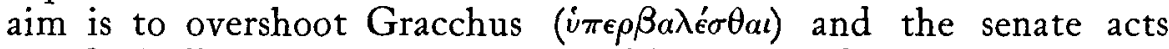
paradoxically in supporting him. The entire business is a stage farce (iss $\dot{\epsilon}^{\prime} \nu \omega \mu \omega \delta^{\prime}(q)$ ). In the case of the proposal touching the colonies, and in that of the proposal to remit the rents of allotments assigned by the agrarian commission, the rhetorical scheme works well. But in the third case, that of the Latins, we have an anti-climax. How could Drusus be said to "overshoot" his opponent, who was ready to give not only the Latins, but all Italians, not merely immunity from flogging but all the privileges which Roman citizens possessed? And there are other considerations. Drusus is ex bypothesi trying to please the Roman voters. If, as many scholars have thought, they were still to be left subject to the whip, how would they be gratified by the proposal to exempt the Latins? And why were not the backs of the other Italian allies to be protected against the lash, as well as the backs of the Latins? It would have cost the Roman citizens nothing. Or why was not the whole provocatio to be opened to allies without distinction on the principles of the law of Flaccus and probably of Gracchus and the lex Acilia? It seems more than likely that the scope of the rogatio of Drusus was wider than that described by Plutarch. Putting aside doubts about the nature of the project, did it pass ? Mr. Caspari asks why Gracchus should have vetoed the boon which Drusus proposed to confer upon the Latins. If Plutarch is right in representing the whole course taken by Drusus and the senate as a comedy, the question is easily answered. And even if Drusus who, according to Suetonius, earned the name patronus senatus, was a sincere democrat, as he has been imagined by some scholars to have been, Gracchus would surely have weakened the case for his own measure by accepting that of Drusus and would have laid himself open to a charge of treachery in abandoning the cause of the allies. But it is not likely that Gracchus was ever called on to use his veto. The moment for exercising the veto was the moment immediately preceding the voting at the comitia, and we have no evidence that the measure was ever presented to the voters.

Mr. Caspari argues that the colonial law of Drusus was carried and that there is therefore a presumption that the law about the Latins was carried also. But did the colonial project of Drusus actually pass into law? This has often been maintained, but the 
evidence for the contention breaks down as soon as it is scrutinised. It is useless to appeal to Appian, i, 35: " $\dot{\boldsymbol{o}} \dot{\delta} \dot{\boldsymbol{\epsilon}}$ (the younger M.

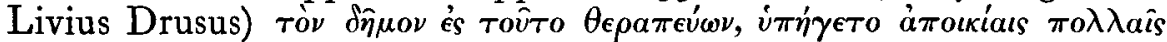

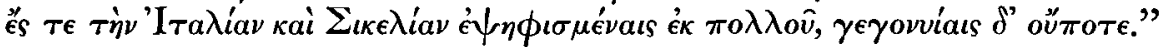
All that this can prove is that some colonies had been voted but not founded. Even if we set aside the colonial law of Saturninus as having been cancelled, the words of Appian need not refer to the rogatio of the elder Drusus. And there is one point in the passage which seems to lead to the contrary conclusion, the mention of Sicily. It is most unlikely, if Drusus really did propose to substitute for the colonies of Gracchus another set, that he would have placed any of these outside Italy. The story of the attempted refoundation of Carthage proves that the idea of extra-Italian colonies was unpopular at the time. And the line even between Italy and Sicily was rigorously drawn. The lex Iulia of 90 в.c. while it enfranchised the Greek Regium, did not enfranchise the Mamertines of Messana, though they were of Italian origin, and their town was only separated from Regium by the narrow strait. Mommsen has somewhere spoken of Messana as having been taken in 264 в.c. into the Italian "Wehrgenossenschaft," but the facts hardly justify the expression.

An examination of the authorities bearing on the colonial law of Gracchus will disclose a better way of explaining the passage in Appian. As is the case with the whole political programme of C. Gracchus, the information which has come down to us in regard to his colonial scheme is vague and confused. To take

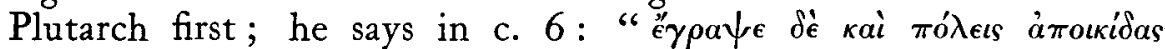
$\epsilon^{\epsilon} \kappa \pi^{\epsilon} \mu \pi \epsilon \sigma \theta a u$," and apparently this belongs to the first tribunate in I23. Then in c. 8 (which, judged by the context, belongs to

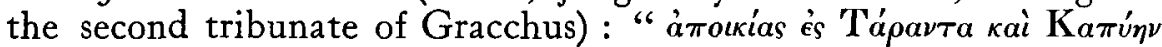

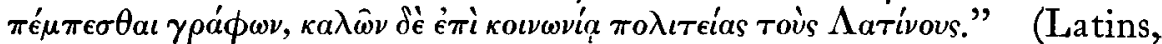
it seems, were to join in these colonies, and to become Romans. But the last clause curiously resembles what Appian i, 23, says of

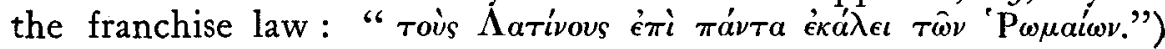
Then in c. 9 we read, in the rhetorical passage which 1 have already discussed, that Gracchus had only proposed two colonies, while Drusus now proposed twelve. Plutarch has forgotten what he wrote in c. 6, where a larger scheme of Gracchus is obviously indicated. Appian has nothing to say of the colonial policy of Gracchus, excepting with reference to the one colony of Carthage. But, curiously enough, he does mention the twelve projected settlements of Drusus, which delighted the populace, and caused them to despise "the laws of Gracchus." The epitomator of Livy omits Drusus from the tale altogether, and speaks of "complures coloniae in Italia et una in solo diruto Carthaginis" as projected by Gracchus. Velleius, ii, 7, denounces as the most pernicious part of the Gracchan legislation the act by which colonies were to be constituted outside 
Italy. If the conservatives of the reign of Tiberius felt thus, what must have been the feelings of the conservatives of I23 B.C. ? Velleius goes on to say that Carthage was the first settlement established without the boundaries of Italy; he then mentions that Narbo Martius was planted three years later, and it is a fair inference that this was included in the scheme of Gracchus. In another passage (i, I5) he states that "Scolacium Minervia" and "Tarentum Neptunia" were founded in I23 B.c. (Tarentum was loosely referred by Plutarch to $\mathrm{r22}$.) This is practically all the information we have about the Gracchan colonies, for the authority of the Liber coloniarum is so slight that its assertion about a number of colonies in Italy, that they were established by a lex Graccana or a lex Sempronia is worth nothing. The mention of Capua by Plutarch is interesting, but it is opposed to statements by Cicero, who praised the Gracchi for not laying hands on the Campanus ager (De Leg. Agr. i, 21 and ii, 8I).

It is obvious then that the range of the colonial scheme of Gracchus was much wider than Plutarch in c. 9 imagined. We have had mention of five contemplated foundations, of which four were certainly in the actual scheme. And these four all bear names of a peculiar pattern, embodying reference to one of the great gods, Carthage being appropriated to Juno. It seems to have been an object with Gracchus to plant the worship of Roman divinities among alien populations, the Greeks, the Punians and the Gauls. The wellknown Senatus consultum, referring to the community of Astypalaea, mentions a law, which must have been inspired by him, connecting foreigners with the temple of Capitoline Jupiter. He may have had an impression that the component peoples of the empire might ultimately be drawn together by means of the Roman forms of religion. If so, the idea, like others of his ideas, was destined to be realised by the emperors, but through a new kind of cult of a pattern taken from the East. In the whole list of Roman colonies (other than titular) there are only four besides which make any reference to divinities in their titles. Sulla created a colonia Veneria at Abellinum and another at Pompeii, and a colony at Telesia had the name Herculanea, and there was Sicca Veneria in Africa. If the colonisation of Capua was projected by Gracchus, the political heir of Gracchus who founded it did not bestow on it a name of Gracchan type; nor did the democrats who planted there in 83 a short-lived colony copy the Gracchan nomenclature, so far as is known. It seems a possible and not over-rash conjecture that in the confused accounts of Plutarch and Appian, the colonies which are credited to Drusus have been transferred to him from Gracchus, who may have intended to allot to twelve new cities the names of the twelve great gods. The counter-stroke of Drusus may have been to increase the number of colonists in each settlement, and 
so to appeal to a lower class than those whom Gracchus had in view

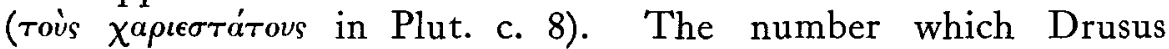
proposed, that is 3,000 , was large for a burgess colony. We do not know what number was fixed by Gracchus, but in the case of the settlement at Carthage, he at once proposed to increase the settlers to 6,000 , a figure quite unprecedented for a burgess colony, and to incorporate men from all over Italy. I believe, therefore, that the unfounded colonies which Drusus the younger intended to bring into existence were the outstanding portion of the Gracchan scheme. Probably a general colonial law was passed by Gracchus authorising the whole number of colonies which were contemplated. This was, most likely, never abrogated; for the foundation of Narbo in 118 B.c. was in pursuance of it. The general law, however, was not sufficient ; a particular enactment in addition was required for each settlement. Special commissioners were needed who, among other things, would lay down the fundamental statute for the government of each of the new cities. These basal laws were not drafted precisely alike; a certain latitude was allowed for the embodiment of local custom. The lex Rubria which concerned Carthage was of course abrogated by the lex Minucia of 121 ; but this was the only one of the series of laws passed by Gracchus or by legislators of his party which the senate had the courage or the power to annul immediately after his death, though another, that one which was intended to prevent the execution of citizens without a regular trial, was broken without being repealed. To return then to the rogatio, by which Drusus intended to free the Latins from the danger of corporal punishment, I can find no reason for assuming that it was ever accepted by the comitia. The only supposed mention of an actual enactment by Drusus refers to the year II 2 when he was consul, and concerns the titles of Latins and peregrini to holdings created out of public land. This is mentioned only in a lacunose passage of the lex agraria and Mommsen, scornfully and it seems correctly, rejects the idea that the lex Livia there mentioned is connected with this Drusus.

We must next consider a story of Scipio Aemilianus at Numantia, given in Livy, ep. 57: "quem militem extra ordinem deprehendisset, si Romanus esset, vitibus, si extraneus, virgis cecidit." This passage shows that already in I34 в.c. a commander was compelled to treat the Roman and the non-Roman differently, and it is preposterous to suppose that the difference was then in favour of the non-Roman. What likelihood is there that by 108 в.c. the position had been reversed ? Gaius Gracchus, in a speech quoted by Gellius, $x$, 3, adduced three instances of outrageous flogging by Roman magistrates; in one case a "nobilissimus bomo" in Teanum Sidicinum, which was a civitas foederata, was "virgis caesus," while in the old Hernican city of Ferentinum a quaestor had suffered the same indignity, and a labourer of Venusia, a Latin colony, had been 
flogged to death in punishment for a jest, by a youthful Roman legatus. These things had taken place, Gracchus said, "nuper." His remedy was of course enfranchisement, and the fragment of his speech supplies one out of many indications that he intended to treat Latins and other Italian allies alike. The contrast between the vitis and the virga will be discussed later.

In the extracts which have been analysed, nothing has appeared to justify the idea that the Latins were ever protected in the manner suggested by Drusus. In fact, Latins and other allies were left in the same position. Pliny, Nat. Hist. vii, I36, says that Balbus, the client of Cicero, was arraigned "de iure virgarum," and the phrase was applicable to all non-Romans. I will now take up a larger and more difficult inquiry, which is bound up with the other, about the degree of protection which was vouchsafed to the Roman citizen. In text-books generally the "liberty of the subject" in the Roman commonwealth, and the guarantees for that liberty, are treated in such a manner that it is difficult to draw clear conceptions from them. Every teacher who has to expound the theme to advanced students discovers this fact. Even in those noble monuments of learning, Mommsen's Staatsrecbt and his Strafrecht, there are a number of statements relating to the matter which are vague, inexact, and confusing. In the latter work, p. 29, Mommsen declares that the law in the time of Gracchus did not explicitly forbid the magistrate to inflict on the Roman citizen the injuries suffered by the men of Ferentinum and Teanum and Venusia, on whose hardships Gracchus expended his eloquence. The only bar was "die in dieser Epoche wohl begründete Rücksicht auf die tribunicisch-comitiale Controle." This somewhat dark pronouncement seems to ignore the descriptions given of the leges Porciae, and the words "wohl begründete" appear to imply that magistrates were restrained only by a custom which had in time become firmly established. On p. 32 we read "die Beseitigung der Geisselung aus der bürgerlichen Coercition hat sich schwerlich auf die Lagerzucht erstreckt." I admit that one of the proofs commonly adduced to prove the opposite opinion is inconclusive. The celebrated coin of Porcius Laeca may have no reference to camp discipline, since the citizen who says "provoco" is dressed in the toga; though the style of the dress is not decisive against the other view. But other considerations are against Mommsen. Of the definite instances which can be quoted of the flogging of Roman soldiers on service during the republican period (apart from beating with the vitis and the fustis, of which I will speak presently), none is later than 205 B.c. This particular instance is given by Livy, xxix, 9, 4 and Valerius Maximus, ii, 7, 4 and 8, mentions two examples of the time of the Samnite wars and the First Punic War. Frontinus Strat. iv, 29, 30, speaks of these occurrences and adds two others from the 
same early time. Some soldiers were flogged and beheaded a fter the great mutiny in Spain, which Livy describes in xxviii, 24 et seqq. In these circumstances, it is reasonable to presume that soon after the Second Punic War, a lex Porcia put a stop to the practice. Mommsen quotes on p. $3 \mathrm{I}$ from Sallust the story of Turpilius which I have discussed, and treats it as demonstrating that by ro8 B.c. a Porcian law had deprived generals of the right to condemn a Roman citizen soldier to death without appeal, while leaving the position of the Latin and allied soldier unchanged. In other words, a general might still order the flogging of a Roman, but might not follow it up by ordering his execution.

I have already mentioned that the instances recorded by Roman writers of verberatio having been inflicted on the Roman soldier are all of the age of the Second Punic War or earlier. But one passage, which gives a general description of punishments in the Roman army remains to be discussed; it is in Polybius, vi, 35-37.

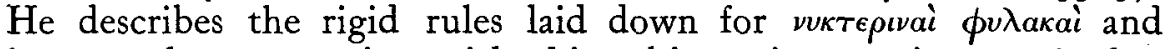
in very close connexion with this subject gives a picture of what happens if an "̈́odos, that is, a soldier whose duty it is to go the

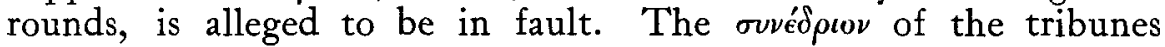
sits on the case and if he is found guilty he suffers fustuarium or

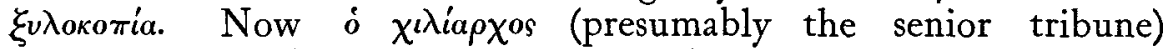
takes a $\xi^{\prime} \lambda o_{\nu}$ and just touches the condemned man with it. Then all the soldiers beat him with their fustes and pelt him with stones;

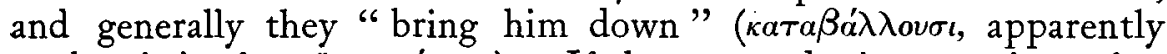

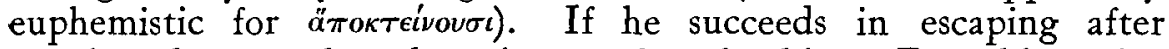
running the gauntlet, there is no safety for him. Even his native place dares not to receive him; so in any case such a punishment is utter ruin. For neglect of duty connected with the nightly round the optio (oujpajos) and the decurio (o $\left.\tau \hat{\eta} s \iota^{i} \lambda \eta s \quad \dot{\eta} \gamma \epsilon \mu \dot{\omega} \nu\right)$ may suffer the same penalty. Then Polybius speaks of other punishments

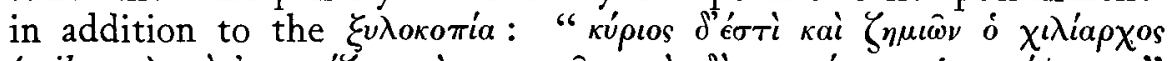

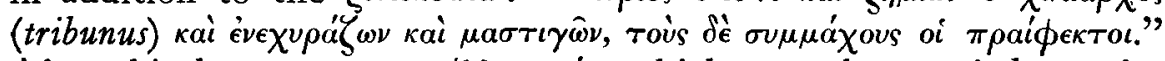

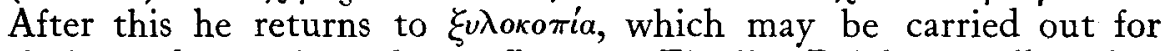
theft and certain other offences. Finally Polybius tells what happens when not merely an individual but a whole detachment is guilty in the same way, or has deserted a position under pressure.

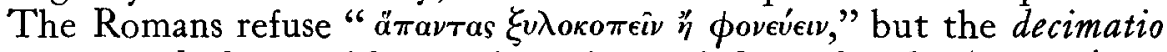
ensues and the punishment is again carried out by the $\xi \nu \lambda о к о \pi i a$.

The passage of course raises difficulties. But one or two things are clear. By $\mu a \sigma \tau \iota \gamma \hat{\omega} \nu$ Polybius indicates a treatment far less serious than the fustuarium; and yet in using the word he has in mind the Latin verberatio, which might imply severe chastisement. But by placing

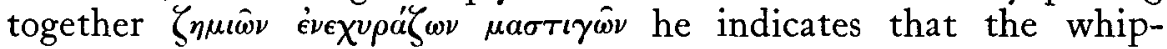
ping he has in mind is a comparatively slight affair. The

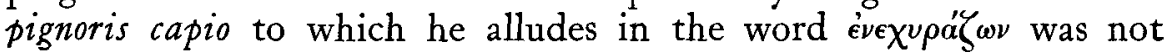


even connected with breaches of military duty, strictly so called; while $\zeta_{\eta \mu \omega} \hat{\omega} \nu$ refers to the docking of pay and similar exactions. Polybius does not definitely refer to the vitis of the centurion; but he makes it quite certain that vitis is not another name for fustis, as has sometimes been supposed, a point to which I will return presently. An unsound deduction which has occasionally been made from this passage is that the allies were only disciplined by their own native officers. This may have been so for the slighter matters of which Polybius is speaking. But the name praefecti is used both of officers who were assigned to each allied contingent in the place where it was levied and also of the Roman officers who commanded the allied forces in any army. These are praefecti socium and they are so often mentioned together with the tribuni that Polybius probably had them in mind here.

It is obviously impossible to make the words of Polybius, which are far from precise, agree altogether with the tenour of the passages previously discussed; and it is likely that this account is not only incomplete but inexact. Suspicion must rest on the prominence

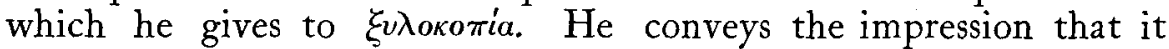
was of very common occurrence, whereas the references to it elsewhere lead to the belief that it was an exceptional form of punishment. Most of the examples connect it with the delinquencies not of individuals but of companies or detachments; and it is generally an accompaniment of decimatio. Speaking of the legio Martia and the legio quarta which deserted Antony, Cicero, Phil. iii, I4, says "si ille consul, fustuarium meruerunt legioness quae consulem reliquerunt." And decimatio itself cannot have been so frequent as the statement of Polybius would make it appear. It is not heard of during the Second Punic War, numerous as were the occasions which might have justified it. In 206 в.c. Scipio had to deal with one of the worst mutinies known in the history of the army. He only punished five ringleaders. Of the recorded instances of actual decimatio, there is none between the age of the war with Pyrrhus, and the campaign of Crassus against Spartacus. Frontinus has an instance of a modification of the decimatio near the age of Crassus (iv, 1, 37). In writing of the decimatio ordered by Crassus, Plutarch, Crass. c. Io, makes out that the punishment was a revival of a forgotten usage, " $\delta \iota \dot{a} \pi o \lambda \lambda \hat{\omega} \nu \chi \chi^{\prime} \nu_{\nu \omega \nu}$ "; and alluding to the fustuarium without naming it, he says "кai yà $\rho$

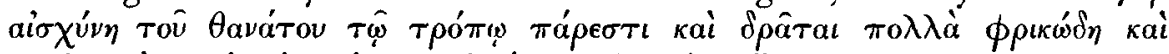

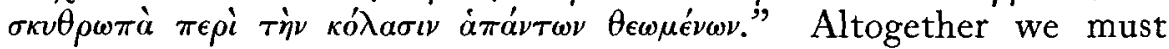
hold that Polybius drew his information partly from books, and treated as ordinary what was extreme and rare. Much else that he conveys in his survey of the Roman polity, for example his account of the dictatorship, is similarly unpractical.

Mommsen, along with Cagnat and others, has confused the 
vitis, the virgae and the fustis. The confusion seems to have arisen in part from a mistaken comparison of the statements of Polybius with those of the epitomator of Livy, 57, where the story from the Numantine war is told. The vitis, the $\mu a \sigma \tau i \xi$ and the fustis have thus been co-ordinated. But I have shown that $\mu \alpha \sigma \tau \iota \gamma o u v$ and

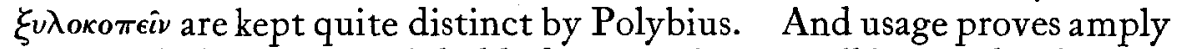
that while fustis was a club, bludgeon, or heavy walking-stick, vitis was a light cane. In Tacitus' Annals, i, 23, a notorious story is told of a centurion who acquired the nickname of "cedo alteram," " another, please," from his habit of breaking his vitis over the soldiers' backs. While the vitis is very frequently mentioned as the symbol of the centurion's authority, we do not hear that he ever carried such a weapon as a fustis. We cannot therefore take Juvenal's epithet nodosa of the vitis (viii, 247) as denoting a heavy stick. Again in the numerous places where there is reference to the Porcian and Valerian laws, so far as they concerned flogging, the virgae are alone mentioned. Apparently it was the only word used in the statutes to indicate the offending instrument; and it was so narrowly interpreted in the camp, that the other two, the vitis and the fustis, were not held to be excluded. On the other hand, in civil life, all instruments of the kind were supposed to be covered by the one term. We shall see later why the virgae were tabooed. The punishment by the vitis was slight; that by the fustis was committed to the soldiers themselves. If we look to the whole history of the virgae in Rome, and particularly to their connexion with the fasces, we must suppose that they were used for flogging at a very early date. It is curious therefore that Mommsen should have suggested that their use was adopted by the Romans from the Macedonian army (Eph. Epigr. vii, 465).

Mommsen is unwilling all through to allow that the laws of appeal could have intended to stop verberatio unless it was an accompaniment of execution. Hence he will have it that the coin of Porcius Laeca refers to execution with flogging, not to flogging separately. In his Strafrecbt, p. 42, he declares that to allow provocatio against flogging would have been " unvernünftig." Surely a most arbitrary assumption; leading to inconsistencies, and to forced treatment of indications in literature. For instance the familiar boast of Cato that he had afforded protection to the shoulders of his fellow-countrymen (Festus, 234) is dealt with in an unnatural fashion. This is taken as referring to a lex Porcia which is "vielleicht dasselbe welche das feldherrliche Imperium unter die Provocation zog; in einer vor der Bürgerschaft gehaltenen Rede kam dies weniger in Betracht als der Schutz des Rückens." Here is a tangle. According to Mommsen scourging was never forbidden on military service. Cato passes a law which still permits it, and only interdicts it when it is succeeded by the infliction of 
death. What becomes of his boast? The soldier was still liable to be scourged; what great service did a legislator render to him, who laid down that he must not be scourged if he was going to be executed? A similar paradox is put forward by Greenidge, in his History, pp. 242, 243, namely that the law of Drusus " must have satisfied many of the Latins" as a substitute for the franchise, although he supposes that they were still liable to be scourged " after the jurisdiction and at the bidding of their own native commanders." It must have been an insignificant fraction of the Latins who could be satisfied by such small mercies. Greenidge of course assumes that the proposal of Drusus passed into law. ${ }^{1}$

What probability is there in the view, advocated by Mommsen, that the "feldherrliches Imperium" was subjected to the provocatio? It must be admitted that not much stress can be laid upon the words of Cicero, De Legibus, iii, 3, 6: "militiae ab eo qui imperabit provocatio ne esto." They form part of his ideal code, which departs, though not very widely, from the actual Roman constitution. But in the numerous passages where Mommsen writes of the matter he only refers to two ancient utterances for proof, apart from the coin of Porcius Laeca of which mention has already been made. The first is the account given by Sallust of the trial of Turpilius. But it is just as natural and easy an inference from Sallust's words, that it was the flogging and not the execution of the citizen (if he was a citizen) which had been forbidden. The other passage is in the speech of Cicero Pro Rabirio perd. reo, $\S 8$. A number of charges against Rabirius had been mentioned by the prosecutor in addition to the chief one, touching the murder of Saturninus. With these side issues, as he deems them, Cicero declines to deal. One charge was " de civibus Romanis contra legem Porciam verberatis aut necatis." Evidently this allegation was connected with Apulia and Campania, for Cicero says that the presence of many enthusiastic supporters of Rabirius from these very districts absolves him from the necessity of replying. It is of course far from easy to see how Rabirius, who had never risen above equestrian rank, could have been guilty of such crimes. It is natural to think, with Mommsen, that "Offizierstrafen" are meant; but if so, they could only refer to the time when all law was dissolved in disorder, after the return of Sulla from the East. Then the want of authority in Rabirius might be the gravamen of the charge. In other words the charge is on a level with that which is based on the slaying of Saturninus. We have to do not with law, but with its negation.

The section on the "feldherrliche Provocation" in the Strafrecht (Achter Abschnitt, $\S 7$ ) is subtle but unilluminating. A sharp

\footnotetext{
1 The statement of Festus, 234, "complures leges erant in cives rogatae quibus sanciebatur poena
} 
distinction is drawn between the "feldherrliche" and the "comitiale Provocation." It is said: "die comitiale Provocation verlangt Aufhebung eines rechtsgültigen Urtheils, die feldherrliche besteht in der Ablehnung eines incompetenten Gerichts. Die comitiale fordert die Entscheidung der Bürgerschaft, die feldherrliche giebt nur die Möglichkeit der Prozessführung vor der competenten Behörde." Just above we read that " die Ablehnung des Feldherrnspruches in ihren Consequenzen auf die comitiale Provocation hinausläuft." Considering how little evidence there is even for the existence of the "feldherrliche Provocation," these dicta are singular exercises of the imagination. Mommsen has somewhere spoken of "phantastisch-juristischer Dogmatismus." Surely we have it here. Can it be supposed that while the law permitted, indeed enjoined upon the magistrate in the city, invested with imperium, to pronounce the sentence against which there was to be the appeal, the magistrate outside the city, equally invested with the imperium, was forbidden to say a word in such a case ? How was he to secure a trial before the comitia on a serious charge ? Was he compelled to find a prosecutor who would lay the case before a magistrate in the city? He must in any case have examined facts and witnesses, that is to say, he must have acted in the first instance precisely as a magistrate would in Rome. It is surely most improbable, even if Mommsen be correct in his view that the commander was subjected to provocatio, that in such matters the magistrate in the city had his imperium limited in one way and the magistrate in the field in another manner.

If there was appeal against a military sentence, how are we to explain the continuance of military executions which run through the republican history to the very end ? What of the fustuarium, which generally resulted in death, and the decimatio, which was sometimes carried out by the axe, sometimes by means of the fustuarium? There is no instance on record of a general having been arraigned on the charge of ordering soldiers to death in defiance of a law. Nor is there any trace of a soldier not being a commander having been tried either by comitia or quaestio for an evil deed committed during his service, though some after reaching Rome were punished without trial. In the numerous stories of indiscipline in the army, there is not a hint that the subjection of military offences to review by civil courts was an inciting cause. There are many tales about generals who curried favour with the troops by indulging them. If the "feldherrliche Provocation" existed, it would have been an easy trick to stop the executions which certainly did go on in camp, and to refer all serious delicts to Rome for judgment. Few theories have been so widely accepted on such slender evidence as that of the "feldherrliche Provocation" against execution. If a statute established this kind of appeal, it would 
have been effectual. We have seen reason to believe that the law which prohibited the use of the virgae in the army really had effect. $\mathrm{R}$. Cagnat, learned as he is in the history of the army, in the course of an article in the dictionary of Daremberg and Saglio on militum poenae, follows Mommsen closely, and the theory is to be found in most books on Roman public law.

I turn now to the protection afforded by legislation against arbitrary punishment within the city. In regard to this subject also it is possible to quote confused and confusing pronouncements from the most distinguished text-books. The fact that the bundles of rods were still carried before the magistrates after the axes had been removed, in obedience to the first lex Valeria, has of course often attracted attention, and has led to the conjecture that for a time after the execution of the citizen was forbidden domi, it was still legal for the magistrate to acquaint his back with the virgae. Some support, but slight, for this view is to be found in statements that have come down to us concerning the Twelve Tables. But Mommsen goes farther. He repeatedly states that not execution altogether was forbidden by the earlier leges Valeriae, but the military form of it, by means of the axe, and that the magistrate was still allowed to scourge a citizen to death in the city. It is surely an extraordinary suggestion that the burgesses preferred to be caesi virgis usque ad necem rather than to be ushered out of the world mercifully and expeditiously by the axe. Mommsen has based his opinion on the very vague information, of late date, which we possess concerning the punishment more maiorum, and on one or two fabulous incidents referred to the earliest days of the republic. It is admittedly impossible to determine precisely the contents of the leges Valeriae and leges Porciae. The ancient references to them are all extremely brief and vague, and that is doubtless because the statutes themselves were vague and brief. It has often been assumed in discussions concerning them that they were elaborate enactments, with careful definitions and exceptions. If this was so, it is strange that extant records include no example of an appeal to the actual wording of these laws, even the latest of the leges Porciae, the text of which must surely have been accessible to the orators and writers of the late republican age. Tradition represented the earliest lex Valeria as having dealt with the securis and the virgae exactly in the same manner. We have seen some slight reason to suppose that this may have been an error. Livy in the well-known passage about the third lex Valeria $(x, 9)$ assumes that it was passed because the aristocratic magistrates had disregarded the provisions of the earlier two: " plus paucorum opes quam libertas plebis poterant." There may be a grain of truth in this view : at all times in Roman history the " paucorum opes" could do much to deprive the criminal laws of their effect. Iivy makes in the same passage the interesting 
statement that the leges Porciae added nothing to the leges Valeriae, excepting a new "sanctio," and Cicero makes the same assertion (Rep. ii, 54). This is fair evidence of their brevity. The Porcian laws were often represented as covering the killing as well as the scourging of a citizen, but usually in speaking of them special stress was laid on the latter, as though this were the point at which the previous laws needed to be strengthened. Hence such descriptions as lex Porcia pro tergo civium lata or pro scapulis. By a tiresome trick, not uncommon in Latin writers, the three Porcian laws are sometimes spoken of as though they were one; and the same is the case with the three Valerian; the opposite form of expression is also found. When Cicero says (Rab. perd. § I2): "Porcia lex virgas ab omnium civium Romanorum corpore amovit," we cannot tell what the exact force of omnium is; whether, for instance, it includes civilians everywhere outside the capital or Italy. They would naturally at first be placed on the same footing as soldiers.

The cases in which the leges de provocatione failed to give protection to the citizen are very numerous. The most striking is that of the "consularisches Nothwehrrecht," as Mommsen calls it, which, in its later stages at least, was accompanied by the "senatus consultum ultimum." Of this Mommsen says (Staatsrecht, i, 3, 150): "diese Ausnahme muss wohl irgendwie in den Gesetzen selbst begründet oder wenigstens theoretisch anerkannt gewesen sein," and he asserts that this was never "gesetzlich abgeschafft." The whole political struggle over the "senatus consultum ultimum" becomes unintelligible if the "consularisches Nothwehrrecht" ever in any form, at any time after the republic began, was authorised by statute. I believe the explanation of this and other exceptions is to be found in quite a different direction. The great part which changing custom as opposed to legislation played in the evolution of civil law in Rome is familiar to every one who knows anything of the subject. On this side the law adapted itself to alterations in public opinion by means of the elastic and expanding and changing praetor's edicts. These written documents gave a precision at all times to this department of public administration which was lacking in others. But there was no section of the public law of Rome which was not amenable to the pressure of varying opinion and custom. There were many things connected with the political framework, which the magistrates could theoretically do, which they rarely or never did. For example, it is only when the republic is dying that we hear of a tribune exercising a veto against the "lex curiata de imperio," but it must have been always technically possible, and have merely been restrained by custom and opinion. So with the criminal law and punishments. It may well be doubted whether any of the apparent breaches of the laws about provocatio were really in accordance 
with statutory exceptions. In some cases a magistrate would be so strongly supported by the general desire of the citizens that it would be safe for him to act. In others he would presume on support, fail to get it and suffer. Whenever the "consularische Nothwehr" was recognised, its recognition was not so much " theoretisch," as " praktisch," in accordance with the circumstances of the moment. Saturninus, for instance, suffered by general consent, and not by the letter of any law. It was Cicero's misfortune that the general consent which he thought existed, was either nonexistent or inefficacious. It is far more likely to have been custom than statutory permission which allowed actors to be whipped, even if they were Roman burgesses, and the paramours of the Vestals to be beaten to death in the forum, or strangled in prison after a flogging sub furca, a servile indignity. It may well be that the extension of the provocatio for the Roman civilian, first beyond the pomoerium, then over Italy, then over the provinces was the work of time and changed ideas more than of legislation. The criminal commissions which were issued by the Senate alone depended on the circumstances of the period for their reception. The general panic in Rome and Italy which was brought about by the so-called Bacchanalian conspiracy of I 86 B.c. condoned the summary execution of numbers of citizens as well as aliens. But general acquiescence was not to be expected when, two or three generations later, the senate put into operation the same engine for the destruction of political opponents.

I turn now to the consideration of some particular cases in which the laws of provocatio seem to have been contravened. They illustrate the fact, which often escapes notice, that the guarantees for the "liberty of the subject" at Rome were valueless in the last resort, if the tribunes of the plebs did not choose to enforce them. When even military offenders were within the city walls, it must have been constitutionally possible for the tribunes to protect them if they chose, excepting against the dictator, so long as his office was exempted from provocatio. We often hear of protection having been afforded by the tribunes in the earlier republican time to men who refused to answer the call to arms. Yet Cicero in his speech for Caecina, $\S 99$, speaks of a practice, as though it were common, whereby "populus eum vendit qui miles factus non est." $\mathrm{He}$ explains it on the principle that a man who refuses to face danger in defence of his freedom has really declared himself to be a slave. Evidently in the latter part of the republican age the tribunes took a different view of these cases from what had sometimes been their view in earlier days; and it cannot be supposed that this was due to a change in statute law. Cicero also says that the people may sell into slavery a man who does not appear at the call of the censors, because he thereby bears evidence against himself that he is not 
in reality a free man. This must have been carried out by the quaestor on a report from the censors. The man was dealt with as public property. An interesting case of a military offender is narrated by Fronto, Strat. iv, 20, and more fully by the epitomator of Livy, 55: “P. Cornelio Nasica et D. Iunio Bruto consulibus dilectum habentibus in conspectu tironum res saluberrimi exempli facta est: nam C. Matienus accusatus est apud tribunos plebis quod exercitum in Hispania deseruisset, damnatusque sub furca diu virgis caesus est et sestertio nummo veniit." Here the tribunes figure as what they often were, an arbitrary court possessing full power to nullify the provocatio by refusing to interpose. The flogging sub furca is part of the man's treatment as a slave. The words of the epitomator show that there can be no question of crucifixion in this case, as Mommsen imagines (Strafrecht, p. 45). Slaves were often subjected to the furca apart from crucifixion, though it was an accompaniment of that punishment. In the so-called supplicium more maiorum the furca was used without the cross. A case precisely like that of Matienus is reported by the epitomator of Livy, I4 and by Val. Max. vi, 3, 4, and by Varro, ap. Non. I8. (In this case the man himself was sold, not merely his goods, as Mommsen says in Staatsrecht, iii, 3, p. 45.) It was the connexion of the virgae with the correction of slaves that caused them to be tabooed in the case of burgesses. Cicero, In Verrem, i, I3, complains about Roman citizens who were by Verres "servilem in modum cruciati atque necati," and we see from ii, 5, I63 that this refers to the use of the rods. Expressions are common such as that used by Dionys. Hal.

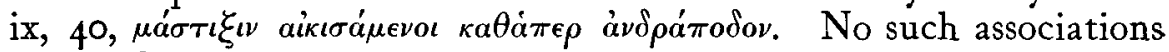
attached to the vitis, or to the fustis, savage as the use of the latter was. It was one thing to be beaten by the captain's light cane, which was used like the rattan on board an English man-of-war in the navy's great days; a weapon which was in constant employment, whereas the "cat-o'-nine tails" was a ceremonial implement. It was quite another thing to be tied to a stake and flogged by a menial. Severe as it was, the fustis was applied not by a lictor or a carnufex, but by a man's comrades.

Valerius Maximus, ii, 7, 15, tells the tale of the Campanians. (cives Romani Campani) who had broken away from the Roman army, and occupied Regium, and after a long occupation of that town were brought to Rome in 271 B.c. and executed by order of the senate. A tribune issued a protest to the senate "ne in cives Romanos contra morem maiorum animadverteret." The natural conclusion from this passage is that the cives sine suffragio possessed the right of appeal; and it is generally accepted. If the tribune was correct in his view of ancestral custom it should have mattered very little whether the exemption had been expressed in statute or treaty or was merely customary. The tribune would in any case have been 
acting constitutionally if he had persisted in his intervention and had vetoed the decree of the senate. Mommsen has expressed different views about the case in different places. In Staatsrecht, iii, 577, he says: "das Provocationsrecht kann an sich dem Halbbürger nicht zugestanden haben, da es auf Comitialgemeinschaft beruht." The introduction of such words as "an sich," "in Princip," "formell " and the like is very characteristic of Mommsen, and it often darkens counsel. His assertion about "Comitialgemeinschaft" must be baseless, for we have seen that provocatio was granted to Latins and allies who fulfilled certain conditions, without any reference to "Comitialgemeinschaft." In Staatsrecht, i, I 32, the protest of the tribune about the Campanians "konnte sich darauf beziehen, dass die Hinrichtungen mehrere Tagen dauerten." It is true that the senate ordered the executions to be carried out at the rate of fifty a day and forbade the burial of the dead and mourning for them; all this for a curious reason "quo minore cum invidia id perageretur." But the tribune, according to Valerius, objected to the punishment in toto and not to its fashion. It would be strange indeed if he had desired to see the whole of the culprits executed on the same day. ${ }^{1}$ In Strafrecbt, p. 43 , as regards these Campanians it is said: "Dass den Campanern das Provocationsrecht zugestanden hat, kann nicht füglich gezweifelt werden; eine Festsetzung darüber hat nicht fehlen können, und hätten sie es nicht gehabt, so wäre der Protest unbegreiflich." What becomes of "an sich"?

Then there is the well known case of Pleminius, who was guilty of atrocities in the south of Italy when the elder Africanus was there, and nearly involved the commander in the same ruin which overtook himself. The old rule, established not by statute but by precedent, that a culprit should be allowed to give vades to appear at his trial and should not be kept in prison, was in his case broken through, and he died in the gaol. Other cases of the kind are recorded, in which the ordinary and established guarantees for the "liberty of the subject," after the first stage in a regular trial before the highest tribunal, were denied the accused, and he was deprived of the Roman privilege which excited the surprise of Polybius, of going into exile and escaping personal punishment. Even Caesar, who did not acknowledge at the time the validity of the "senatus consultum ultimum," proposed to inflict penalties on the Catilinarians which were quite incompatible with the statutes about provocatio (Sall. Cat. 5I ; Cic. in Cat. iv, ro). Mommsen speaks of the course taken by Cicero, in calling for a vote in the senate on the punishment of Catiline's associates, as unprecedented. That may be so, in so far as proceedings in connexion with the senatus consultum ultimum 
are concerned. But this was a late invention, and in earlier days the senate did pass resolutions about extraordinary punishments, as in the case of the cives Romani Campani mentioned above.

It does not seem to have been customary for the tribunes to shelter against the police low-class criminals, even when they were citizens. Sometimes, when criminal offences occurred on a large scale, the senate established commissions which tried and condemned culprits without regard to the laws of appeal. But also in everyday life and in individual instances, glaring crime was punished with little more formality than that of the drumhead court-martial. The action of the tresviri capitales would be covered by the inaction of the tribuni, whenever these were cognisant of the circumstances, and did not choose to interfere; and was of course justified when the criminal might have appealed to the tribunes and did not do so. In most of the cases with which the police commissioners dealt, it would be known to the criminal that an appeal would be of a certainty without effect. A manifest murderer or other villain of low degree would appeal in vain, while a high-born or wealthy scoundrel would be sure of a trial before a regular and often benevolent tribunal. The Roman law frankly respected persons to an appreciable extent, even under the republic, and to an enormous extent under the empire, as the division between bonesti and bumiliores testifies. This fact serves to explain many passages in literature which assert or imply that, provocatio notwithstanding, it was possible to inflict verbera and vincula on the citizen, and even to execute him. Many of those whom in 44 в.c. the consul Dolabella summarily hurled from the Tarpeian rock or crucified were certainly burgesses (Cic. Phil. i, 3, and $A d A t$. xiv, I5 and I6). Antony followed suit in the same year. They ignored restrictions on their imperium, and having physical force and probably opinion on their side, could set statute law at defiance. Even when Tiberius Gracchus, then a sacrosanct tribune, and his followers were massacred by a movement which was a purely private and unofficial enterprise, the senate was able to protect Nasica, who had captained it, against punishment for the most glaring infraction not only of the laws about provocatio, but of the leges sacratae also, which had ever occurred. The formal criminal commissions which were issued by the senate without recourse to the comitia were at one time condemned, at another condoned, by the burgesses themselves when the commissioners came before them for trial. On these occasions custom, circumstance, panic, ephemeral opinion, even the blatant clamour of an insignificant portion of the body politic would often be of greater force than statute. What was possible in one age was not possible in another; what could be done at one moment could not be done at another in the same age; and all this without change of law. When tribunes in the last century of the republic tried to hurl men of distinction 
from the Tarpeian rock, in reliance on musty, perhaps imaginary precedents, presumed to have been drawn from the execution of the leges sacratae, whose text hardly a tribune of the period could have seen, they were easily restrained. If the time had ever existed for such action, it had long gone by. The want of logic in the Roman practice of punishment is illustrated by the treatment of the men who had made compacts with an enemy, which had afterwards been repudiated by the government. C. Hostilius Mancinus, who had saved a Roman army from destruction by entering into an agreement with the Numantines, was offered to the enemy when the undertaking was broken, and declined by them, and, as he had technically lost his citizenship, it was restored to him by special enactment. But no offer was made to surrender to Jugurtha the two commanders who made agreements with him that were afterwards repudiated. The case of M. Claudius, who is said to have concluded peace with the Corsicans when only in the position of a legatus, is peculiar; he was either executed in prison (Val. Max. vi, 3, 3) or exiled (Zonaras, viii, 8).

There was the same irregularity in dealing with minor penalties. Probably infames of all kinds were liable to be scourged, like actors, if the police found them to be a nuisance. When Horace spoke of a man as "sectus flagellis triumviralibus" he did not merely adopt a circuitous method of saying that the man had been a slave or an unprotected alien. It is more likely that the poet meant to brand him as a mean citizen, for whom the protecting laws were of no avail. And of course the flagellum was even a more cruel implement than the virgae. Verres when praetor urbanus was "solitus virgis plebem Romanam concidere" (Cic. Verr. ii, 1, I 22). When in tumults at Rome the pilleus or cap of liberty was hoisted like a banner, as by Saturninus, the ancient historians interpreted it as a call to the slaves to rise, but it may well at times have had another signification, that of an invitation to citizens to resent infractions of their statutory freedom. Sometimes passages bearing on this subject have been loosely interpreted in discussions. Thus in Sallust's oratio Macri the orator denounces the nobles for their narrow idea of the freedom of the Roman burgess: "libertatem rati, quia tergis abstinetur et huc ire licet atque illuc, munera ditium dominorum. Atque haec eadem non sunt agrestibus, sed caeduntur inter potentium inimicitias donoque dantur in provincias magistratibus." This has been taken to mean that no law forbade the scourging of the legionary soldiers. Its true sense is just the opposite. Outside the city, the nobles are often able to set the Porciae leges at nought, in contravention of usual practice and general opinion.

That Mommsen did an immense service to scholarship by bringing the Roman constitution within the legal atmosphere in his Staatsrecht and by surveying the criminal law of Rome in his Strafrecbt 
from a more strictly legal standpoint than his predecessors had assumed, is beyond question. And nothing that I have said must be taken to mean that I do not entertain profound admiration for his achievements. But he has not infrequently tried in vain to trace in the public law the spirit which dominates the private law of the Roman commonwealth. This has led him to stretch the institutions of the state, in their governing and repressive functions, on a Procrustean bed of regularity. No one has seen more clearly than Mommsen that the shadow of the absolute imperium hangs over the whole history of the Roman state in all its departments. The civil law was, in a formal sense, the outflow of the uncontrolled imperium. The praetores made law by virtue of it, but they used it merely as a qualification for making law, and in their actual lawmaking were dominated by a sense of the momentousness of orderly development. In the sphere of administration and in particular of administration as connected with public safety, the traditions that hung round the imperium produced the opposite result. Not unnaturally the imperium domi chafed against legal and customary restrictions to which the imperium militiae was not subject, until all legal restraints and in part the restraint of custom also vanished in the imperium as enjoyed by the emperors. Before the end came, although Roman orderliness generally stood in the way of wilful caprice, there was naturally a certain amount of irregularity which cannot be forced into the framework of law. The substitution of the one supreme executive authority with lifelong tenure for the changing colleagues of the republic had on the whole a steadying effect on the course taken by law in regard to crime. Criminal administration under the empire was not the régime of caprice which a hasty reading of Tacitus tends to bring before the imagination. On the administrative side, the empire made as a rule for regularity and even for rigidity. The Roman had of course at all times a remarkable reverence for custom and precedent; without it his republic would have been utterly unworkable. But however deep may be the regard for administrative custom, it changes under the stress of practice and interpretation no less than the custom which is strictly legal. In the republican age there was no official record of administrative precedents, and they must have been difficult for the magistrate, and still more for the ordinary citizen to discover. But precedents created by the emperor were naturally recorded. Near the end of the republican time, the greatest scholar of the day set forth in writing for the benefit of a consul: who had never before filled a civil office the rules which governed the business of the senate. Gellius, xiv, 7, 2 describes his work

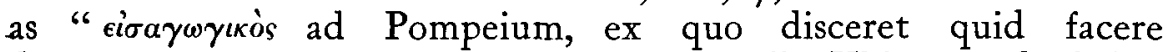
dicereque deberet cum senatum consuleret." This was doubtless the portion of the consul's duties where forms were most rigidly 
required and observed. Outside the senate, precedents would not have the same force, and would be greatly more difficult to ascertain.

I have purposely kept out of sight everything connected with the periods when the old republic was formally suspended, under Sulla, and the dictatorship of Caesar, and all that happened after the republic ceased to exist. A certain amount of evidence derived from those times would be available for illustrating the conclusions stated, but it would have had to be disentangled from confusing details.

In conclusion, I will draw further attention to Caesar's inconsistencies in his attitude towards the senatus consultum ultimum. Cicero, In Catil. iv, ro, naturally criticises the "homo mitissimus atque lenissimus" who "non dubitat P. Lentulum aeternis tenebris vinculisque mandare," and proposes "publicatio bonorum" in addition; all this without regular trial. Only a few months before the question of the legality of the senatus consultum had been directly tried out in the case of Rabirius. It is curious that neither in Cicero's speeches against Catiline, nor in the debate on the Catilinarians, as reported by Sallust, is there any reference to this case, although Caesar was deeply concerned with it, and as Cicero afterwards said, "Rabiri causa continebatur omne ius retinendae maiestatis." But nowhere in connexion with the case of Catiline is it either asserted or implied that statute law made any exception in favour of the " consularische Nothwehr." Caesar speaks, in Sallust's account, of the proposal to execute the conspirators as novum consilium and genus poenae novum, curiously ignoring precedents. It certainly does not appear that he "erkennt das Recht des Senats an" (Mommsen, Staatsrecht, iii, 3, I243), in spite of his illogical compromise. In a number of passages, as has been said, Mommsen has treated the "Nothwehr" on the part of the senate as legal and probably statutory; but it is interesting to observe that on one occasion he was swept away by a sudden blast of what may be called his Cicero-phobia, and described Caesar's speech as "die Rede gegen Ciceros ebenso unpolitischen wie unmenschlichen Justizmord" (Strafrecht, p. 173). It is not often that this great exponent of history condemns drastic action by authority as " unmenschlich." It may be noted that whenever Cicero talks of the "Nothwehr," he places the purely informal and disorderly murder of Tiberius Gracchus on the same level with the formally authorised slaughter of Gaius Gracchus and of Saturninus. $\mathrm{He}$ could not have spoken in this way if any enactments had mentioned the senate in connexion with this kind of shedding of blood. When the question of punishing the Catilinarians was under consideration, neither party, so far as can be seen, appealed to such resolutions of the senate in the form of the senatus consultum ultimum, or 
in the other form, really equivalent, of a declaration against the publicus bostis, as had been passed in the period of disorder after Sulla's consulship. By common consent these were treated as invalid.

When Caesar's whole early course with regard to these declarations by the senate of a "state of siege" is remembered, his later words with regard to them cannot be read without astonishment. In that deeply interesting passage where he summarises in a speech to his soldiers his grievances against the senate (B.C. $i, 7$ ), he speaks of the famous resolution of the senate passed on January 7 th in the year 49 , and calls it a " novum in republica introductum exemplum ut tribunicia intercessio notaretur atque opprimeretur." Even Sulla, he declares, never annulled the intercessio of the tribunes; a hard saying, in view of certain facts. Then "quotienscumque sit decretum, darent operam magistratus ne quid res publica detrimenti caperet (qua voce et quo senatus consulto populus Romanus ad arma sit vocatus), factum in perniciosis legibus, in vi tribunicia, in secessione populi, templis locisque editioribus occupatis, atque haec superioris aetatis exempla expiata Saturnini atque Gracchorum casibus docet." Here he seems to justify the death of the elder Gracchus with which no decree of the senate had anything to do, equally with that of Saturninus, the illegality of which he had tried to establish in the case of Rabirius. And he seems to give the whole democratic case away when he constitutes the senate as judge of what is a perniciosa lex and what is vis tribunicia. It is strange that the man who was in many respects the political heir of the Gracchi, should have whitewashed their execution, after using for his own purpose during many years the agitation against the legality of such proceedings. Did he feel that the régime of liberty, as hitherto understood, was over, and was he now unwilling to condemn a practice which might conceivably aid in establishing a régime of authority? Was his change of view brought about by the disorders of the ten years which preceded the Civil War? But he had aided and abetted the disorders, and had little personal right to complain of the final decision of the senate directed against himself. The political game played on his side and on the other was really $\dot{\omega} s \dot{\epsilon} \nu \kappa \omega \mu \nu \delta \dot{\alpha} \alpha$, and in this game constitutional precedents and principles were not more than counters, to be discarded when no longer useful. 